DOI: https://doi.org/10.18524/2519-2523.2021.16.245739

УДК 050(477):28]“1882/1906”

\title{
RECEPTIONS OF THE MUSLIM WORLD ON THE PAGES OF "KIEVSKAYA STARINA"
}

\section{Yevhen Filianin}

Postgraduate student at the Department of History of Ukraine, Oles Honchar Dnipro National University

Gagarin Avenue, 72, Dnipro, Dnipropetrovsk Oblast, 49000, Ukraine.

ORCID: https://orcid.org/00000001-5934-5263

E-mail: yevhenfilianin@gmail.com

Citation: Filianin, Ye. (2021)

Receptions of the Muslim world on the pages of "Kievskaya starina".

Chornomors 'ka mynuvshyna, vol. 16, pp. 57-64.

Submitted: 16.11 .2021

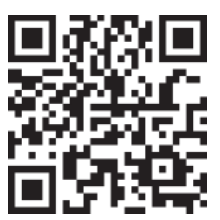

\section{Annotation}

The purpose of this article is to study the receptions of Islam and Muslim cultures in the Ukrainian public sphere of the late XIX - early XX centuries, using "Kievskaya starina" journal as an example. The content of the journal, specifically its thematic focus is analyzed. The materials related to the study of Islamic cultures are highlighted and analysis of their texts is conducted. The article by M. Drahomanov "Turkish anecdotes in Ukrainian folk literature" is studied. Author's attitude to the problem of studying oriental cultures by historiography of the late XIX century is covered. M. Drahomanov's dissatisfaction with insufficient degree of studies on Muslim people by late XIX century scholars and his desire to make these studies relevant to academic community is established. The study pointed at author's awareness of significant intercultural ties between ethnic groups of Ukrainians, Turks and Tatars. The facts depicting $M$. Drahomanov's emphasis on the importance of intercultural factor in the formation of folk art and the relations between his thoughts and conventional views of the late XIX - early XX century are presented. The analysis of the review of "The Notes of the Crimean Mountain Club" article on the relations between Zaporozhia and Crimea by L. Lvov is carried out. The presence of the ideas about close interconnection of the Ukrainian and Tatar history in Ukrainian public sphere of the late XIX century is established. Good evaluation of such ideas in the mentioned discourse is depicted. The article makes a statement that there is a significant potential for further study of the receptions of Islam in the Ukrainian public sphere of the late XIX-early XX century.

Key words: reception studies, public sphere, Islam, "Kievskaya starina", Crimean Tatars, Turks, Turkish folklore.

\section{РЕЦЕПЦІЇ МУСУЛЬМАНСЬКОГО СВІТУ НА СТОРІНКАХ "КИЕВСКОЙ СТАРИНЫ"}

\section{Евген Філянін}

Аспірант кафедри історії України, історичний факультет

Дніпровський національний університет імені Олеся Гончара Проспект Гагаріна, 72, м. Дніпро, 49000, Україна

ORCID: https://orcid.org/00000001-5934-5263

E-mail: yevhenfilianin@gmail.com

\section{Анотація}

Стаття присвячена вивченню рецепиій ісламу та мусульманських культур в украӥнській публічній сфері кіния XIX - початку XX cm. на прикладі періодичного видання "Киевская старина:. Проведений аналіз тематичної направленості матеріалів, представлених y часописі, на предмет безпосереднього вивчення мусульманської культури. Виділено роботи, щзо пов'язані із дослідженням даної проблеми, проаналізовано їхній зміст. Як найбільш показова 
Цитування: Філянін Є. Рецепції мусульманського світу на сторінках “Киевской старины". Чорноморська минувшина: записки Відділу історії козацтва на півдні України: зб. наук. пр. / за. ред. В.А. Смолія. Одеса: ФОП Бондаренко М.О., 2021. Вип. 16. C. 57-64.

Отримано: 16.11.2021 p. проаналізована стаття М. Драгоманова "Турецкие анекдоть в украинской народной словесности”, яка демонструє ставлення автора до проблеми вивчення східних культур історіографією кіния XIX $\mathrm{cm}$. Встановлено невдоволення дослідника низьким ступенем вивчення культур ісламської традичії його сучасниками та браком прагнення до актуалізаџіï теми серед наукової спільноти. При дослідженні компаративної сторони статті з'ясовано наявність у автора думки про існування значних міжкультурних зв'язків між етнічними групами українців, турків та татар. Надано факти, щзо зображують позицію M. Драгоманова щзодо значення етнічного та культурного факторів на формування народної творчості та відношення між його думкою та

поглядами тогочасної науки. Проведений аналіз рецензї на роботу Л. Львова про відносини між Запорожжям та Кримом, щуо містилась у "Записках Крымского Горного Клуба". Встановлено присутність в украӥнській публічній сфрері кіния XIX cm. ідей про тісний зв'язок українського та татарського минулого та зображено наявність високих оцінок подібних ідей. Висунуто твердження про існування значного потенщіалу щуодо подальшого вивчення рецепцій ісламу в українській публічній сфері кіния XIX-початку XX cm.

Ключові слова: рецепиії, украӥнська публічна сфера, іслам, "Киевская старина", кримські татари, турки, турецька народна творчість.

Протягом століть українці перебували у помітній близькості із європейськими та східними культурами. Інтенсивна взаємодія Заходу та Сходу простежується у багатьох сферах культурного та повсякденного життя. Особливо це характерно території Південної України, що історично постає як мультикультурний регіон із великою етнічною та релігійною різноманітністю місцевого населення. Вивчаючи його, важко оминути увагою контакти українського етносу із мусульманським населенням, що в своїй більшості надане кримськотатарським та турецьким народами.

Суспільно-політичне середовище та культурні процеси, що спостерігаються в світі, часто слугують контекстом для виникнення наукових досліджень. Вони породжують суспільну актуальність, яка, у свою чергу, впливає на формування наукових інтересів. Сучасний світ $€$ великою мірою глобалізованим. Ми можемо спостерігати становлення міцних зав'язків між різними регіонами світу в політичному, економічному та культурному аспектах. Це сприяє посиленню інтеракцій між представниками різних культур, часом помітно відмінних між собою. Для забезпечення ефективності спільної роботи та добробуту у співіснуванні постає необхідність у вибудовуванні механізмів толерантності, що, у свою чергу, починається із усвідомлення іншої культури. Панування ліберальних цінностей в Західному світі тільки посилюють цю тенденцію. Як наслідок, ми спостерігаємо підвищену увагу до проблем мультикультурності серед науковців на глобальному рівні. У свою чергу, через вплив західних тенденцій та існування власного суспільно-політичного фону схожа ситуація прослідковується і в українській історичній науці. Як результат, інтерес сучасної історіографії до дослідження мусульманської складової історії України зумовлюється не тільки науковою, але ще й суспільною актуальністю.

Сьогодні проблема історичної взаємодії України зі східними культурами користується науковою зацікавленістю ряду дослідників, серед яких можемо виділити М. Якубовича [18], О. Яроша [19]. Проте вивчення сюжетів, пов'язаних із мусульманськими культурами, не зародилося в межах останніх десятиліть. На різних етапах розвитку української історіографії ми можемо спостерігати наданій увазі до даної проблематики. Залежно від історичних обставин кількісні та якісні характеристики цієї уваги природнім чином варіюються. 
Кінець XIX - початок XX ст. - період, що помітним чином відрізняється від сучасного нам у політичній ситуації, соціально релевантних проблемах, культурних поглядах тощо. Очевидним є, що в цей час наукова думка перебувала в помітно іншому стані - відрізнялася пануюча методологія та ставилися інші задачі. Ці два фактори мають впливати на формування суспільної та наукової актуальності проблематики досліджень відмінних від сучасних. Таким чином, у публічному просторі ми очікуємо аутентичного відображення тогочасної свідомості, в тому числі і щодо питання сприйняття східних культур.

Одним 3 найбільш знакових у відображенні української наукової та публічної думки можна вважати журнал “Киевская старина: (1882-1906)”. Журнал об'єднав на своїх сторінках українську інтелігенцію, містив у собі дослідження 3 української історії, археології, фольклористики, літературознавства. Ще за часів свого видання привернув до себе увагу наукової спільноти як на території України, так і серед українських дослідників в еміграції. M. Грушевський включив розділ "Киевской старины” “Историография 1880-1890 гг. Лазаревский и кружок “Киевской старины” до фундаментальної роботи “Украинский народ в его прошлом и настоящем”, що закріпило за часописом його вагоме наукове та загальнокультурне значення. Журнал сприяв розвитку історичної науки, розширив іiі джерельну базу. Однак, крім цього він ще й вмістив у собі відображення основних ідей та поглядів культурно-просвітницького руху української інтелігенції та іiі прагнення до національного відродження [13, с. 275-278]. Останнє робить часопис цінним джерелом для вивчення рецепцій українських інтелектуалів.

Слід відзначити, що за весь час існування часопису, тематика опублікованих тут досліджень залишалась, здебільшого, в рамках україноцентризму. У переважній більшості увага приділялася питанням, пов'язаних із історією українського етносу. Тому виняткові сюжети, що відображають історію та культуру інших народів, заслуговують на особливу увагу. Аналіз змісту журналу за весь період його існування, дозволяє стверджувати, що на його сторінках знайшлося місце сюжетам, які безпосередньо торкалися проблематики ісламу чи мусульманського населення в історії України. До таких можемо віднести: “Задунайськая Сечь (по местным воспоминаниям и разсказам)" Ф. Кондратовича [3], "Распоряжение генералгубернатора Глебова по случаю проезда турецкого посланника через г. Киев (1764 г.)” (А. А.) [15]; “Лист” печерского архимандрита Иннокентия Гизеля на сбор милостыни для выкупа у татар ленника" (Повід. А. Л.) [8]; “Письма протоиерея Арсения Лебединцева, б. благочинного церквей южного берега Крыма, к преосвященному Иннокентию, архиепископа Херсонскому и Таврическому, с донесениями о ходе военных действий и состоянии церквей и духовенства во время 11-ти месячной осады Севастополя" [14]; “Сведения о походе в Крым Михаила Дорошенка" К. Мельника [11]; “Странствования чумака, бурсака и раба” (Повід. Н. М.) [17]; “Где жыли Переяславские торки?” А. Стороженка [16]. Промовисті назви засвідчують, що передусім друкувалися матеріали, які стосувалися історії українців та їхніх різнопланових зв'язків із мусульманським світом. Показовими є листи А. Лебедінцева, який переймався станом православних церков у Криму. Поява листа із такою географією уваги на сторінках україноцентричного видання заслуговує на окрему увагу та роздуми. Їх підсилюють художні твори на сторінках часопису: “Останній Гирей” (М. Л.), [10]; “Роксолана” Г. Комарової [2] та "Під Мінаретами” М. Коцюбинського [4].

До вищенаданого переліку можна включити ще кілька робіт, зміст яких заслуговує окремої, більш детальної уваги. В публічному просторі 1880-х рр. ми можемо спостерігати зацікавлення українських дослідників східним фольклором. Яскравим прикладом цьому слугує стаття, написана М. Драгомановим під псевдонімом П. Кузьмичевський [13, с. 275] “Турецкие анекдоты в украинской народной словесности». Маємо грунтовний аналіз генезису та еволюції українських анекдотів, що з'явилися в побуті під впливом східних культур. Вже на початку статті автор звертає увагу на контекст розвитку української народної творчості, де чітко стверджує, що мало не половина сторінок “південно руської” історії пов'язані із народами «турецького племені”. Мова йде про хозар, печенігів, половців, торків та інших аж до сучасних М. Драгоманову “константинопольських турків”. Отже, як мінімум протягом 
тисячоліття представники українського етносу та їхні предки перебували в тісних контактах зі східними народами, що супроводжувалися війнами, співпрацею, шлюбами, мали наслідком асиміляцію та широкі культурно-побутові запозичення. М. Драгоманов актуалізує питання щодо недостатньої відомості про цю інтеракцію сучасній йому науці. Окрім певної кількості досліджень тюркізмів у місцевій мові, відсутні навіть спроби розпочати до вивчення подібної проблематики [6, с. 209]. Це дає нам підстави вважати наступне. По-перше, станом на 1880-ті pp. проблема тюркського компоненту історії України не була належним чином науково досліджена, а розробка даних питань обмежувалася лише окремими поодинокими роботами. По-друге, поява дослідження М. Драгоманова (особи вкрай впливової серед української інтелігенції та суспільно активної молоді) та, тим більше, постановка проблеми про недостатнє наукове вивчення тематики може вказувати на піднесення інтересу щодо досліджень мусульманської складової в історії українських земель.

М. Драгоманов передусім значну увагу приділяє пошукам витоків низки анекдотів, що побутували на українських теренах. Значна частина тих, що прийшли із Туреччини, побудовані на образі Наср-Еддина Ходжи, блазня Тамерлана. В турецькому наративі його зображення постає доволі неоднорідним - від простака до хитрого “плута". Розповіді про нього стали популярними по всій турецькій Азії, Африці та Європі, потім почали переходити до народів, які мали близькі контакти з турками. Прикладом подібних є вірмени, грузини, болгари, серби, румуни й українці. Анекдоти про згадану особу доходили навіть до терен Італії. При цьому його ім'я зазнавало змін [6, с. 210-212].

Витоки деяких із цих анекдотів М. Драгоманов прослідковує аж до сюжетів, закладених у Талмуді [6, с. 215]. Аналізуючи єврейські, турецькі, українські, європейські та російські варіанти наративу, автор дійшов висновку щодо родословної близькості українського анекдоту турецькому, а часом і до італійського аналогу. В той самий час «великоруські» варіанти можуть значно відрізняться від усіх вище перерахованих [6, с. 217-218].

М. Драгоманов також звертає увагу на певні особливості та зміни, що відбуваються при запозиченні. В окремих сюжетах спостерігається зміна етнічної належності дійових осіб. Таким чином, на місці турецького персонажа в українській версії може постати циган або єврей [6, с. 225]. Також неодноразово автор зауважує, що в турецьких анекдотах не менше, або навіть більше гумору та більше сенсу й резонності в мотивах історії. Як приклад М. Драгоманов наводить наступні сюжети. Перший - український, про батька й сина. Батько й син сіли обідати гарячим борщем. Син з’їв першу ложку й відчув, що страва занадто гаряча, така, що аж очі сльозитися стали. На батькове питання “Чого се ти, сину, плачеш?”, хлопець відповів, від того, що той один син в сім'ї. Батько потім сам скуштував борщу й обпікся. Після цього сказав, що хай краще б той єдиний син взагалі пропав. Другий анекдот - турецький аналог про Наср-Еддина. Подібна ситуація: дружина Ходжі випадково з'їла занадто гарячу ложку супу. В неї почалися сльозитися очі. Жінка сказала, що просто згадала покійного батька. Коли ж Ходжа сам скуштував страву і обпік язика, то відповів тим, що краще б його теща, помираючи, забрала би з собою і свою доньку [6, с. 221-223].

Виявивши коріння деяких розповідей в індійській творчості, М. Драгоманов хвалить турецькі варіанти за те, що в них краще збережені оригінальні сатиричність та сенс, порівняно iз європейськими відголосками [6, с. 235-236]. До того ж, українські варіанти часом характеризуються як "значно більш злі" [7, с. 462-463]. На додачу, наданий у статті аналіз контактів української культури із мусульманськими культурами Сходу не обмежується лише тюркським світом. Ми можемо спостерігати висвітлення арабських аналогів турецьких анекдотів і порівняння із турецькими і українськими варіантами заради з'ясування шляхів розповсюдження народних розповідей. У статті фігурує твердження про те, що арабський варіант одного із анекдотів об'єднує у собі основи українських редакцій кількох розповідей, включаючи розповідь про Наср-Еддина та його дружину [7, с. 453-454].

Цікавим видається й зауваження М. Драгоманова щодо збігу народних розповідей українців та італійців. Подібна ситуація спостерігається і в порівнянні української творчості із “грецькою(ново)”. На думку автора, це має пояснюватися однаковим впливом 
“Константинополя, християнського і мусульманського” на країни Чорного та Середземного морів. М. Драгоманов дійшов висновку, що "Всупереч думці вчених старої школи, зараз виявляється, що схожість культурних відносин має значно більше значення у справі схожості народних сказань, ніж племінна спорідненість" [6, с.232]. В наведеній тезі важливо виділити дві думки. По-перше, висловлюється підтримка ідеї, що при формуванні та генезі народної творчості гомогенність етнічної культури може поступатися зовнішньому впливу інших культур. Така ситуація виникає навіть при сильних відмінностях народів у їхньому світогляді та системі цінностей. Саме таким чином зображується зв'язок фольклору турків-мусульман із християнськими народами Чорноморського та Середземноморського регіонів. По-друге, подібні твердження вступали у суперечность із поглядами консервативної частини українського наукового осередку і кидали виклик поширеним на той час уявленням.

М. Драгоманов завершує свою статтю зауваженням, що після балканських народів українці найбільше засвоїли сюжети про Наср-Еддина і вкотре пояснює це близькістю та багатообразністю відносин українського народу із турками та кримськими татарами. Через це автор висловлює побажання, щоб була звернена увага на дослідження татарської усної словесності, оскільки вони можуть надати багато цінної інформації про міжкультурний обмін в регіоні [7, с. 466].

Отже, М. Драгоманов мав неоднозначну думку щодо народів ісламської традиції в минулому України. Дослідник безперечно мав усвідомлення тісного зв'язку української історії iз татарським та турецьким факторами, що, в свою чергу, зумовлювало щирий науковий інтерес до вивчення культур турків та татар. Однак це не заперечує й ставлення до турків і татар як до грабіжників та поневолювачів українців - рабовласники та работорговці [1]. Дане зауваження видається особливо продуктивним при порівнянні поглядів М. Драгоманова із змінами у сучасній українській історіографії, яка так само часто констатує як конфронтацію, так і взаємодію українців із кримськими татарами та турками.

Загальні думки М. Драгоманов щодо ісламу заслуговують на довгу цитату: “Тоді турки, покоривши собі багато християнських народів - греків та братніх їм слов'янських сербів i болгар та молдаван, з прожогу думали завоювати трохи не цілий світ. Та й віра турецька заставляла їх воювати з християнами. Віру цю проповідував спершу араб Магомет, більш як тисячу двісті років назад, шістсот років після Христа. Магометанська віра згоджується 3 християнською у тому, що признає одного Бога, та тільки не признає Трійці. Христос у Магомета був великий пророк, але менший від його, а не син Божий. Молитви і пости у магометовій вірі інакші, ніж у християнській, жінок дозволяє Магомет брати більш ніж одну, а на тому світі праведному, мовляв, дано буде силу жінок. Найправедніший, начебто, буде той, хто більше ширив віру магометову. Одну тільки цю віру магометанці вважають за праву, а всі інші то погані, нечисті. Людей іншої віри магометанці велять воювати і силоміць повертати у свою віру" [1].

На сторінках "Киевской старины" можна побачити ще одну коротку, але надто промовисту публікацію щодо сприйняття мусульманського світу в українському інтелектуальному публічному просторі. В бібліографії примірника за червень 1896 рік опублікований текст “Записок Крымского Горного Клуба” 1895 р., № 3 і № 6-12. Кримський гірський клуб - перша в Російській імперії туристична організація серед засновників та перших членів якої були вчені, юристи, письменники, відомі дослідники Криму [5]. В “Записках...” міститься огляд статті Л. Львова про відносини між Запорожжям та Кримом. Мова йде про невелику книгу “Отношения между Запорожьем и Крымом”, видану 1895 року в Одесі [9]. В ній Л. Львов звертав увагу, що козацьке населення не було в змозі обійтися без постійних відносин із Кримом. Через знаходження під впливом сильних геополітичних сусідів, таких як Польща, Москва, Крим та Туреччина, козацька політика виявлялася у намаганнях урівноважити їхні сили, не допускаючи домінування жодного із цих утворень в регіоні. При цьому, запорожці усвідомлювали, що існування козацтва обумовлювалося тільки існуванням Кримського Ханства, а саме Запорожжя протягом своєї історії поставало перед Кримом як у статусі ворога, так й у статусі союзника і, навіть, підданого [12, с. 105-106]. 
Автор “Записок...” з-поміж переказу фактів політичного життя Запорожжя виділяє ту частину роботи Л. Львова, де йдеться про торгові відносини козацтва та татар, як про один із головних факторів їх зближення. Козацтво могло чинити економічний тиск на хана, перешкоджаючи вивозу солі з Криму, що було одним із важливих джерел фінансових надходжень. Проте, відзначається, що згідно з роботою Л. Львова роль козацтва не обмежувалася прикордонною вартою проти татар. Запорожці усвідомлювали, що їхнє існування обумовлюється наявністю Кримського Ханства та черпали звідти культуру, тактику та особовий склад. На це вказує розповсюдженість у козацьких колах прізвищ чи прізвиськ татарського походження. Сусідство двох народів, не дивлячись на багатовікову боротьбу, сприяло зближенню. Більше того, Л. Львов заперечує те, що війна цих двох народів розвивала у них фанатичну ненависть до іновірців. Як доведення коректності цієї тези надається факт переходу козаків у Туреччину після подій 1775 р., при тому, що пам'ять про підкорення мусульманам тоді ще була свіжою. На думку дослідника це є вагомим аргументом на користь того, що ненависть до ісламської культури не становила домінуючої риси козацтва й поступалася більш значимим інтересам [12, с. 106-107].

Текст “Записок...” завершується висловлюванням думки про прикрість того, що стаття Л. Львова була написана в маловідомому виданні [12, с. 107]. Це говорить про високу оцінку якості роботи та наявність в ії тексті вагомої цінності для науковців того періоду. Разом 3 тим, у цій статті кінця XIX ст. наявні думки близькі сучасному науковому дискурсу стосовно взаємовідносин козацького та татарського (православного та ісламського) населення на Південноукраїнському фронтирі. Отже, констатуємо схожі тенденції розвитку української суспільної думки кінця XIX - початку XX ст. із сучасними, які набувають широкого інтересу на початку XXI ст.

Аналіз вмісту «Киевской старины» очікувано демонструє яскраво виражену тенденцію україноцентризму, що є зрозумілим з огляду на стан розвитку українського інтелектуального простору та відповідний етап національного відродження, а також роль журналу як рупору Київської Громади. Зрозуміло, що у такому виданні роботи, присвячені вивченню східних культур, зокрема мусульманських, могли б взагалі бути відсутніми. Але факт їхньої наявності (хоча і в невеликій кількості) видається достатньо промовистим. Публікація на сторінках часопису художніх творів, присвячених мусульманським народам i культурі тільки підсилюють дане враження. Сама лише присутність подібних текстів у дискурсі україноцентричної інтелектуальної спільноти свідчить про наявність певної релевантності даної тематики. Дослідники кінця XIX - початку XX ст., які займалися вивченням турецької та татарської складової української історії, виражали думку про необхідність актуалізації аналогічних сюжетів, а їхні погляди й оцінки часто збігаються з ідеями сучасної української історіографії та суспільної думки.

\section{Джерела та література:}

1. Драгоманов М. П. Про українських козаків, татар та турків: $з$ дод. про життя Михайла Драгоманова. Київ : Дніпро, 1991. 43 с.

2. Комарова Г. Роксолана. Киевская старина. 1904. Т. 85 (июнь.) С. 597-604.

3. Кондратович Ф. Задунайская Сечь (по местным воспоминаниям и рассказам). Киевская старина. 1883. Т. 5 (янв.). С. 27-66.

\section{4. Коцюбинський М. Під Мінаретами (Оповідання). Киевская старина. 1905. Т. 88 (март). С. 373-} 422.

5. Крымский горный клуб. URL: http://surl.li/arcte (дата звернення: 04.11.2021).

6. Кузьмичевский П. Турецкие анекдоты в украинской народной словесности. Киевская старина. 1886. Т. 14 (февр.). С. 209-239.

7. Кузьмичевский П. Турецкие анекдоты в украинской народной словесности (Окончание). Киевская старина. 1886. Т. 14 (март). С. 445-467.

8. “Лист” печерского архимандрита Иннокентия Гизеля на сбор милостыни для выкупа у татар пленника / сообщ. А. Л. Киевская старина. 1895. Т. 48 (февр.). С. 53-54. 
9. Львов Л. Отношения между Запорожьем и Крымом. Одеса : Тип. Штаба Округа, 1895. 60 с.

10. М. Л. Останній Гирей. Киевская старина. 1904. Т. 85 (апр.). С. 74-102.

11. Мельник К. Сведения о походе в Крым Михаила Дорошенка. Киевская старина. 1896. Т. 55 (нояб.). С. 274-286.

12. Отношения между Запорожьем и Крымом. Л. Львова. (Записки Крымского Горн. Клуба). Киевская старина. 1896. Т. 53 (июнь). С. 105-106.

13. Палієнко М. Місце журналу «Киевская старина» в українській історіографії. Спеціальні історичні дисиипліни: питання теорії та методики. Число 5 ; Історіографічні дослідження в Украӥні. Вип. 10 ; [к сб. в целом] Об'єднаний вип. : зб. наук. пр. на пошану акад. В. А. Смолія. Київ, 2000. Ч. 2. С. 275-314.

14. Письма протоиерея Арсения Лебединцева, б. благочинного церквей южного берега Крыма, к преосвященному Иннокентию, архиепископу Херсонскому и Таврическому, с донесениями о ходе военных действий и состоянии церквей и духовенства во время 11-ти месячной осады Севастополя. Киевская старина. 1896. Т. 52 (янв.). С. 1-9.

15. Распоряжение генерал-губернатора Глебова по случаю проезда турецкого посланника через г. Киев (1764 г.) / сообщ. А. А. Киевская старина. 1892. Т. 36 (янв.). С. 146-148.

16. Стороженко А. Где жили Переяславские торки? Киевская старина. 1899. Т. 64 (февр.). С. 283-290.

17. Странствования чумака, бурсака и раба / сообщ. Н. М. Киевская старина. 1897. Т. 59 (окт.). С. 16-20.

18. Якубович М. М. Іслам в Україні: історія і сучасність. Вінниця : ТОВ «Нілан-ЛТД», 2016. 264 c.

19. Ярош О. А. Іслам у публічній сфері: теорії та суспільні практики : наук. вид. Київ, $2020.76 \mathrm{c}$.

\section{References:}

1. Drahomanov, M.P. (1991) Pro ukrainskykh kozakiv, tatar ta turkiv: $z$ dod. pro zhyttia Mykhaila Drahomanova. Kyiv: Dnipro. [in Ukrainian].

2. Komarova, H. (1904) Roksolana. Kievskaya starina, June, pp. 597-604. [in Ukrainian].

3. Kondratovich, F. (1883) Zadunayskaya Sech' (po mestnym vospominaniyam i rasskazam). 4. Kievskaya starina, Jan., pp. 27-66. [in Russian].

4. Kotsiubynskii, M. (1905) Pid Minaretamy (Opovidannia). Kievskaya starina, Mar., pp. 373422. [in Ukrainian].

5. Krymskyy hornyy klub. [online] Available at: <http://surl.li/arcte> [Accessed 04 November 2021]. [in Russian].

6. Kuzmychevskyy, P. (1886) Tureckiye anekdoty v ukraynskoj narodnoj slovesnosti. Kievskaya starina, Febr., pp. 209-239. [in Russian].

7. Kuz'mychevskyj, P. (1886) Tureckiye anekdoty v ukraynskoy narodnoy slovesnosty (Okonchanye). Kievskaya starina, Mar., pp. 445-467. [in Russian].

8. A.L. red. (1895) «List» pecherskoho arkhimandrita Innokentiya Hizelya na sbor mylostyni dlya vykupa u tatar plennika. Kievskaya starina, Febr., pp. 53-54. [in Russian].

9. L'vov, L. (1895) Otnosheniya mezhdu Zaporozh'em i Krymom. Odesa: Typ. Shtaba Okruha. [in Russian].

10. M.L. (1904) Ostannii Hyrei. Kievskaya starina, Apr., pp. 74-102. [in Ukrainian].

11. Mel'nyk, K. (1896) Svedeniya o pokhode v Krym Myxayla Doroshenka. Kievskaya starina, Nov., pp. 274-286. [in Russian].

12. Zapiski Krymskogo Hornogo Kluba (1896) Otnosheniya mezhdu Zaporozh'em i Krymom. L. L'vova. Kievskaya starina, June, pp. 105-106. [in Russian].

13. Paliyenko, M. (2000) Misce zhurnalu «Kievskaya starina» v ukrainskii istoriohrafii. Specialni istorychni dyscypliny: pytannia teorii ta metodyky [Chyslo 5]. Istoriohrafichni doslidzhennia v Ukraini, issue 10, ch. 2. pp. 275-314. [in Ukrainian]. 
14. Pys'ma protoyereya Arseniya Lebedinceva, b. blahochynnoho tserkvej yuzhnoho bereha Kryma, k preosvyashhennomu Innokentiyu, arkhyepyskopu Khersonskomu y Tavricheskomu, s doneseniyamy o hode voennykh deystvyy i sostoyaniy tserkvey y dukhovenstva vo vremya 11-ty mesyachnoj osady Sevastopolya. (1896) Kievskaya starina, Jan., pp. 1-9. [in Russian].

15. A.A. (1892) Rasporyazhenie heneral-hubernatora Khlebova po sluchayu proezda tureckoho poslannika cherez h. Kiev (1764 h.). Kievskaya starina, Jan., pp.146-148. [in Russian].

16. Storozhenko, A., 1899. Hde zhyly Pereyaslavskye torky? Kievskaya starina, Febr., pp. 283-290. [in Russian].

17. N.M. red. (1897) Stranstvovaniya chumaka, bursaka i raba. Kievskaya starina, Oct., pp. 16-20. [in Russian].

18. Yakubovych, M. (2016) Islam v Ukraini: istoriia i suchasnist. Vinnytsia: TOV «NilanLTD». [in Ukrainian].

19. Yarosh, O. (2020) Islam u publichnii sfery: teorii ta suspilni praktyky: nauk. vyd. Kyiv. [in Ukrainian]. 